\title{
Dipeptide Metabolites from the Marine Derived Bacterium Streptomyces acrymicini
}

\author{
Isara L. C. Hernández ${ }^{a}$, Mario L. Macedo ${ }^{a}$, Roberto G. S. Berlinck ${ }^{*, a}$, Antonio G. Ferreira ${ }^{b}$ and \\ Mirna J. L. Godinho ${ }^{c}$ \\ ${ }^{a}$ Instituto de Química de São Carlos, Universidade de São Paulo, CP 780, 13560-970 São Carlos - SP, Brazil \\ ${ }^{b}$ Departamento de Química, Universidade Federal de São Carlos, CP 676, 13565-905 São Carlos - SP, Brazil \\ ${ }^{c}$ Departamento de Ecologia e Biologia Evolutiva, Universidade Federal de São Carlos, CP 676, \\ 13565-905 São Carlos - SP, Brazil
}

\begin{abstract}
A investigação química do extrato bruto obtido a partir do meio de crescimento do actinomiceto Streptomyces acrimycini isolado de sedimentos marinhos levou ao isolamento de dois dipeptídeos: a 8-amino-[1,4]diazonano-2,5-diona (1) e leucil-4-hidroxiprolina (3). Os compostos foram isolados a partir do seu meio de crescimento por uma série de etapas cromatográficas e identificados pela análise de seus dados espectroscópicos. O esqueleto macrocíclico da 8-amino-[1,4]diazonano-2,5diona foi descrito apenas uma vez nas marinobactinas, sideróforos isolados a partir de uma bactéria marinha do gênero Marinobacter.
\end{abstract}

The chemical investigation of the crude extract obtained from the growth media of the marinederived actinomycete Streptomyces acrimycini isolated from marine sediments led to the isolation of two new dipeptide derivatives: 8-amino-[1,4]diazonane-2,5-dione (1) and leucyl-4-hydroxyproline (3). The dipeptides were isolated from the growth media by a series of chromatographic steps, and identified by analysis of spectroscopic data. The macrocyclic carbon backbone of 8-amino$[1,4]$ diazonane-2,5-dione has been previously reported only once in marinobactins, siderophores isolated from the marine bacterium Marinobacter $\mathrm{sp}$.

Keywords: 8-amino-[1,4]diazonane-2,5-dione, leucyl-4-hydroxyproline, Streptomyces acrimycini

\section{Introduction}

Marine microorganisms constitute the latest and yet poorly explored source of new biologically active secondary metabolites, mainly because it is assumed that marine microbiology is still a starting research field, and that microbiology methods should be improved in order to enable the isolation and growing of marine microorganisms in artificial media. ${ }^{1,2}$ We have recently started a program aimed to investigate the secondary metabolites of marinederived microbial strains. ${ }^{3}$ Several fungi and bacteria were isolated from sediments, algae and invertebrates, and were grown in different media in order to evaluate their production of secondary metabolites. Crude extracts obtained from the culture media were subjected to different chemical and biological screenings. Based on ${ }^{1} \mathrm{H}$ NMR analysis, the crude extract of the actinomycete Streptomyces acrimycini was selected for a chemical investigation. We report here the

\footnotetext{
* e-mail: rgsberlinck@iqsc.usp.br
}

isolation and structure determination of two new dipeptide metabolites isolated from S. acrimycini: 8-amino-[1,4]diazonane-2,5-dione (1) and leucyl-4-hydroxyproline (3).<smiles>N[C@@H]1CCCNC(=O)CNC1=O</smiles>

1<smiles>CC(=O)NCCc1ccc(O)cc1</smiles>

\section{Experimental}

\section{General experimental procedures}

IR spectra were recorded on a FT-IR Bomem MB102 infrared spectrometer. NMR spectra were run either on a 
Bruker AC-4.7 Tesla spectrometer, on a Bruker ARX 9.4 Tesla instrument, or on a Bruker AMX500 11.75 Tesla instrument. All the NMR spectra were obtained at $25{ }^{\circ} \mathrm{C}$ using tetramethylsilane as internal reference. High resolution EI mass spectra were obtained on a VG-7070 equipment. Solvents employed for extraction and column chromatography were glass distilled prior to use. TLC analysis were performed with Aldrich precoated TLC sheets of silica gel on polyester with $254 \mathrm{~nm}$ fluorescent indicator eluting with two eluents: hexanes-ethyl acetate 1:1 and $\mathrm{CH}_{2} \mathrm{Cl}_{2}-\mathrm{MeOH}$ 9:1. Plates were developed by observing at $254 \mathrm{~nm}$ and subsequently by spraying with ninhydrin in ethanol and further heating at $120^{\circ}$.

Microorganism collection, isolation and growth. S. acrimycini was isolated from samples of sediments collected with a Kojak apparatus, at depths between 12 and $15 \mathrm{~m}$ in the São Sebastião channel (north coastline of São Paulo state, Brazil). Samples of sediments were immediately processed at the Marine Biology Station of the Universidade de São Paulo. Aliquots of sediments were inoculated in Petri dishes containing different culture media. Marine streptomycetes were selected using standard growing conditions $(\mathrm{g} / \mathrm{L})$ : soluble starch 10.0 , casein 1.0, agar 15.0, pH 7.0-7.5. Spread plates were incubated at $25^{\circ} \mathrm{C}$ during two weeks, then single colonies were harvested and restreaked for purity.

Streptomyces acrimycini was identified by morphological and physiological analyses (carbon sources, sugars fermentation and enzymatic assays) and by chemotaxonomic analyses (cellular wall amino acids, fatty acids composition, rDNA $16 \mathrm{~S}$ sequencing). A voucher sample is deposited at the Deutsche Sammlung von Mikroorganismen und Zellkulturen, under the code 02042 SS99BA-4.

\section{Isolation of 1, 3 and 4 from Streptomyces acrimycini}

S. acrimycini was grown in $10 \mathrm{~L}$ of marine broth 2216 (Difco) with $1 \%$ soluble starch, at $25^{\circ} \mathrm{C}$ during 5 days at $200 \mathrm{rpm}$. Culture media was processed as follows: after filtration on Whatman paper \#1, ethyl acetate was added to the culture medium and left overnight under magnetic stirring. The mycelium was extracted with $\mathrm{MeOH}$. The ethyl acetate was separated from the culture medium aqueous phase by liquid-liquid partition. The EtOAc and $\mathrm{MeOH}$ extracts were pooled and concentrated to $300 \mathrm{~mL}$ of a MeOH$\mathrm{H}_{2} \mathrm{O}$ suspension which was partitioned against hexanes. The $\mathrm{MeOH}-\mathrm{H}_{2} \mathrm{O}$ layer was concentrated, dissolved in $\mathrm{MeOH}$ and subjected to chromatography on Sephadex LH-20 (MeOH), yielding eight fractions which were analysed by ${ }^{1} \mathrm{H}-\mathrm{NMR}$ and by thin-layer chromatography. Based on the chemical and spectroscopic analyses, the fourth fraction was selected for further fractionation by HPLC ( $\mu$ Bondapak $\mathrm{C}_{18}, \mathrm{MeOH}-$ $\mathrm{H}_{2} \mathrm{O} 3: 7$ ), yielding $1.2 \mathrm{mg}$ of a mixture of $N$-acetyltyramine (4) and leucyl-4-hydroxyproline (3), as well as $1.0 \mathrm{mg}$ of pure $N$-acetyltyramine (4). The fifth fraction arising from the Sephadex LH-20 fractionation was further fractionated by a series of HPLC separations on a $\mu$ Bondapak $\mathrm{C}_{18}$ column ( $\mathrm{MeOH}-\mathrm{H}_{2} \mathrm{O} 3: 7$, then $\mathrm{H}_{2} \mathrm{O}$-acetonitrile 6:4) and finally purified on an CSC-Inertsil ODS-2 column ( $\left.\mathrm{H}_{2} \mathrm{O}-\mathrm{MeOH} 9: 1\right)$, to yield $1.4 \mathrm{mg}$ of 8 -amino-[1,4]diazonane-2,5-dione (1).

6-amino-[1,4]diazonane-2,5-dione (1). Glassy solid, $[\alpha]_{\mathrm{D}}-6.8^{\circ}$ (c $\left.0.08, \mathrm{MeOH}\right)$. IR (film) $v_{\max } / \mathrm{cm}^{-1}: 3332$ (br, $\left.v_{\mathrm{N}-\mathrm{H}}\right), 2925\left(v_{\mathrm{C}-\mathrm{H}}\right), 1668\left(v_{\mathrm{C}=\mathrm{O}}\right.$, amide I), $1456\left(v_{\mathrm{C}-\mathrm{N}}\right)$, 1309, 1108, 1002. HREIMS $\mathrm{m} / z 154.07392$ (calc. for $\left.\mathrm{C}_{7} \mathrm{H}_{10} \mathrm{~N}_{2} \mathrm{O}_{2}, 154.07423\right)$ corresponding to $\left[\mathrm{M}-\mathrm{NH}_{3}\right]^{+}$. EIMS m/z (rel. intens.): 154 (78) $\left[\mathrm{M}-\mathrm{NH}_{3}\right]^{+}, 111$ (100), 98 (31), 84 (77), 83 (96), 70 (77), 66 (83). ${ }^{1} \mathrm{H}$ and ${ }^{13} \mathrm{C}$ NMR data: see table 1 .

Leucyl-4-hydroxyproline (3) and N-acetyltyramine (4). Glassy solid. LC-ESIMS m/z (rel. intens.): 245 (2) $[\mathrm{M}+\mathrm{H}]+$, 229 [M-CH$\left._{4}\right]^{+}$(60), 202 (100). Negative-mode HRFABMS $m / z, 243.13476$ (calc. for $\mathrm{C}_{11} \mathrm{H}_{19} \mathrm{~N}_{2} \mathrm{O}_{4}, 243.13448$ ) corresponding to $\left[\mathrm{M}-\mathrm{H}^{+}\right]^{-} .{ }^{1} \mathrm{H}$ and ${ }^{13} \mathrm{C}$ NMR data: see Table 1.

$N$-acetyltyramine (4). Glassy solid. Spectroscopic data in agreement with literature values.

\section{Results and Discussion}

Streptomyces acrimycini was grown in $10 \times 1 \mathrm{~L}$ erlenmeyer flasks, each one containing $500 \mathrm{~mL}$ of enriched marine broth (see Experimental), during 10 days at 180 rpm and $27^{\circ} \mathrm{C}$. Chromatography of the organic crude extract on Sephadex LH-20 (MeOH) yielded several fractions which were further purified by reversed phase chromatography ( $\mu$ Bondapak $\mathrm{C}_{18}, \mathrm{MeOH}-\mathrm{H}_{2} \mathrm{O} 3: 7$ ). The dipeptide 8-amino-[1,4]diazonane-2,5-dione (1) was obtained as a glassy solid, $[\alpha]_{\mathrm{D}}-6.8^{\circ}(\mathrm{c} 0.08, \mathrm{MeOH})$, with a formula $\mathrm{C}_{7} \mathrm{H}_{13} \mathrm{~N}_{3} \mathrm{O}_{2}$ established by HREIMS at [M-NH $]^{+}$ (observed: 154.07392; calculated: 154.07423) and analysis of the NMR spectra. The infrared spectrum of 1 presented bands at 3332 (broad, $\left.v_{\mathrm{N}-\mathrm{H}}\right) 2925\left(v_{\mathrm{C}-\mathrm{H}}\right), 1668\left(v_{\mathrm{C}=\mathrm{O}}\right.$, amide I) and $1456 \mathrm{~cm}^{-1}\left(v_{\mathrm{C}-\mathrm{N}}\right)$, indicating the presence of amide bonds. No significant absorption was observed in its UV spectrum. Analysis of the ${ }^{1} \mathrm{H},{ }^{13} \mathrm{C}$ and gHMQC NMR spectra obtained in DMSO- $d_{6}$ indicated the presence of one methine, four methylenes and two carbonyl quaternary carbons, strongly suggested a dipeptide structure. The methine was assigned to a typical alpha amino acid moiety (CH-8, 4.23, brt, $9 \mathrm{~Hz})\left({ }^{13} \mathrm{C} 58.4\right)$, which showed a coupling in the ${ }^{1} \mathrm{H}-{ }^{1} \mathrm{H}$ COSY spectrum to $\mathrm{CH}_{2}-7$ at $\delta 2.34(\mathrm{~m})$ and 1.99 (m) $\left({ }^{13} \mathrm{C} 28.2\right)$. The $\mathrm{CH}_{2}-7$ methylene protons were 
Table 1. ${ }^{1} \mathrm{H}$ and ${ }^{13} \mathrm{C}$ NMR assignments of compounds $\mathbf{1}$ and $\mathbf{3}$

\begin{tabular}{|c|c|c|c|c|c|}
\hline Position & $\delta{ }^{13} \mathrm{C}^{\mathrm{a}}$ & $\begin{array}{l}\mathbf{1} \\
\delta{ }^{1} \mathrm{H}(\text { mult, } J \text { in } \mathrm{Hz})^{\mathrm{b}}\end{array}$ & Position & $\begin{array}{c}\mathbf{3} \\
\delta{ }^{13} \mathrm{C}^{\mathrm{c}}\end{array}$ & $\delta{ }^{1} \mathrm{H}(\text { mult, } J \text { in } \mathrm{Hz})^{\mathrm{d}}$ \\
\hline NH-1 & & $8.00(\mathrm{bs})$ & $\mathrm{NH}-1$ & & n.o. \\
\hline $\mathrm{CH}_{2}-2$ & 46.2 & $3.99(\mathrm{~d}, 17) 4.11(\mathrm{~d}, 17)$ & $\mathrm{CH}_{2}-2$ & 53.7 & $3.21(\mathrm{~d}, 12) ; 3.47(\mathrm{dd}, 4,12)$ \\
\hline $\mathrm{C}-3$ & 169.9 & & $\mathrm{CH}-3$ & 67.0 & $4.27(\mathrm{bs})$ \\
\hline $\mathrm{NH}-4$ & & $8.10(\mathrm{~s})$ & $\mathrm{CH}_{2}-4$ & 36.6 & $1.93(\mathrm{~m}) ; 2.02(\mathrm{dd}, 7,13)$ \\
\hline $\mathrm{CH}_{2}-5$ & 45.1 & $3.53(\mathrm{~m})$ & $\mathrm{CH}-5$ & 57.1 & $4.38(\mathrm{dd}, 7,10)$ \\
\hline $\mathrm{CH}_{2}^{2}-6$ & 22.4 & $2.02(\mathrm{~m}) ; 1.97(\mathrm{~m})$ & $\mathrm{OH}-3$ & - & $5.08(\mathrm{~d}, 3)$ \\
\hline $\mathrm{CH}_{2}^{2}-7$ & 28.2 & $2.34(\mathrm{~m}) ; 1.99(\mathrm{~m})$ & C-6 & 166.6 & \\
\hline $\mathrm{CH}_{2}^{2}-8$ & 58.4 & $4.23(\mathrm{bt}, 9)$ & $\mathrm{NH}-7$ & & $7.98(\mathrm{bs})$ \\
\hline \multirow[t]{6}{*}{ C-9 } & 164.4 & & $\mathrm{CH}-8$ & 52.5 & $4.04(\mathrm{dd}, 7,13)$ \\
\hline & & & $\mathrm{CH}_{2}-9$ & 37.7 & $1.33(\mathrm{ddd}, 7,8,13) 1.75(\mathrm{~m})$ \\
\hline & & & $\mathrm{CH}-10$ & 24.0 & $1.86(\mathrm{~m})$ \\
\hline & & & $\mathrm{CH}_{3}-11$ & 22.7 & $0.84(\mathrm{~d}, 3.3)$ \\
\hline & & & $\mathrm{CH}_{3}-12$ & 23.0 & $0.86(\mathrm{~d}, 3.3)$ \\
\hline & & & $\mathrm{C}-13$ & 170.7 & \\
\hline
\end{tabular}

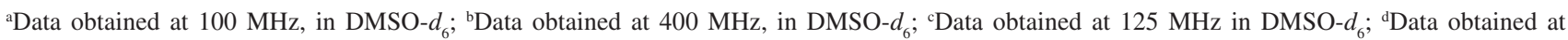
$500 \mathrm{MHz}$ in DMSO- $d_{6}$.

coupled to $\mathrm{CH}_{2}-6$ at $\delta 2.02(\mathrm{~m})$ and $1.97(\mathrm{~m})\left({ }^{13} \mathrm{C} 22.4\right)$, which was in turn coupled to the $\mathrm{CH}_{2}-5$ methylene group at $\delta 3.53(\mathrm{~m})\left({ }^{13} \mathrm{C} 45.1\right)$. Both ${ }^{1} \mathrm{H}$ and ${ }^{13} \mathrm{C}$ chemical shifts of $\mathrm{CH}_{2}-5$ agreed with a $\mathrm{N}$-substitution. These data were indicative of an ornithine residue, confirmed by analysis of the gHMBC spectrum. The remaining NMR data indicated the presence of a glycine residue, with a single methylene group at $\delta 3.99(\mathrm{~d}, 17 \mathrm{~Hz})$ and $4.11(\mathrm{~d}, 17 \mathrm{~Hz})$ $\left({ }^{13} \mathrm{C} 46.2\right)$ coupled with two carbonyl carbons at $\delta 169.9$ (C-3) and 164.4 (C-9). We first considered that the structure of this compound corresponded to the diketopiperazine cyclo[Gly-Orn] (2). ${ }^{4}$ However, analysis of the NMR data in DMSO- $d_{6}$ disfavoured this hypothesis, since a ${ }^{1} \mathrm{H}$ coupling in the ${ }^{1} \mathrm{H}-{ }^{-} \mathrm{H}$ COSY spectrum between $\mathrm{CH}_{2}-5$ at $\delta 3.53$ with the NH-4 amide exchangeable proton at $\delta 8.10$ was observed. Additionally, both $\mathrm{CH}_{2}-5$ at $\delta 3.53$ and NH-4 proton at $\delta 8.10$ showed long-range couplings to the carbonyl group at $\delta$ 169.9. Therefore, in order to account for the NMR data obtained in DMSO- $d_{6}$, the structure should have a lactam group including the ornithine $\delta$ amino group and the glycine acid group, corresponding to 8 -amino-[1,4]diazonane-2,5-dione (1). We have been unable to establish the stereochemistry of the ornithine residue in $\mathbf{1}$ due to the small amount of compound isolated. To the best of our knowledge, the structure of $\mathbf{1}$ is totally unprecedent among dipeptides. A related macrocyclic dipeptide has been recently reported as part of the macrobactins, a group of amphiphillic siderophores recently isolated from Marinobacter sp. ${ }^{5,6}$

The second dipeptide isolated from S. acrimycini was the linear leucyl-4-hydroxyproline (3), isolated in a mixture with $N$-acetyltyramine (4). Due to the small quantity of the mixture $(\sim 1 \mathrm{mg})$, we have not attempted to separate both compounds in order to avoid any loss of material. Since we have been also able to isolate a pure sample of $4,{ }^{7}$ we could analyse the MS and NMR data of $\mathbf{3}$ and $\mathbf{4}$, in order to assign the ${ }^{1} \mathrm{H}$ (at $500 \mathrm{MHz}$ ) and ${ }^{13} \mathrm{C}$ (at $125 \mathrm{MHz}$ ) signals of both compounds. Analysis of the gHSQC spectrum enabled us to assign all hydrogen bearing carbons of $\mathbf{3}$. The position of the hydroxyl group in the 4-hydroxyproline moiety was established by analysis of the ${ }^{1} \mathrm{H}-{ }^{1} \mathrm{H}$ COSY spectrum, which showed sequencial couplings from $\mathrm{H}-5(\delta 4.38)$ to $\mathrm{H}-4 \mathrm{a}$ $(\delta 1.93)$ and $\mathrm{H}-4 \mathrm{~b}(\delta 2.02)$, from these two hydrogens to $\mathrm{H}-$ $3(\delta$ 4.27), which was in turn coupled with both $\mathrm{H}-2 \mathrm{a}$ ( $\delta 3.21$, overlapped by the $\mathrm{H}_{2} \mathrm{O}$ signal in DMSO- $d_{6}$ ) and $\mathrm{H}-2 \mathrm{~b}(\delta 3.47)$. Since the spectra were obtained in DMSO- $d_{6}$, we have been able to observe a vicinal coupling between H-3 and the hydroxyl proton at $\delta 5.08(\mathrm{~d}, J 3 \mathrm{~Hz})$. Further support to the 4-hydroxyproline moiety of $\mathbf{3}$ was obtained by analysis of the gHMBC spectrum, which showed couplings between $\mathrm{H}-5$ and C-4 $(\delta 36.6)$, between $\mathrm{H}-5$ and the carbonyl group C-6 at $\delta 166.6$, between H-3 and C-5 $(\delta 57.1)$, between $\mathrm{H}-4 \mathrm{~b}$ and $\mathrm{C}-2(\delta 53.7)$ as well as between $\mathrm{H}-4 \mathrm{~b}$ and C-3 ( $\delta 67.0)$, between H-4a and C-5, and finally between $\mathrm{H}-2 \mathrm{a}$ and $\mathrm{C}-3$. The amide bond between the two amino acid residues was established as the carbonyl group $\mathrm{C}-6$, which chemical shift at $\delta 166.6$ typically resonates at a higher field than the carbonyl group chemical shift of a free carboxylic acid group. Additionally, analysis of the gHMBC spectrum showed long-range couplings between the exchangeable amide $\mathrm{N}-\mathrm{H}$ proton at $\delta 7.98$ and C-6 $(\delta 166.6)$, between the $\mathrm{N}-\mathrm{H}$ proton and $\mathrm{C}-5$ of 4-hydroxyproline $(\delta 57.1)$, as well as between $\mathrm{H}-8$ of leucine $(\delta 4.04)$ and C-6 of 4-hydroxyproline. Analysis of the gHMQC, ${ }^{1} \mathrm{H}-{ }^{-1} \mathrm{H} \mathrm{COSY}$ and gHMBC spectra defined all hydrogen and carbons of the leucine moiety. ${ }^{1} \mathrm{H}-{ }^{1} \mathrm{H}$ couplings were observed between 
H-8 and $\mathrm{H}-9 \mathrm{a}(\delta 1.33)$ and $\mathrm{H}-9 \mathrm{~b}(\delta 1.75)$. Further hydrogen couplings were observed between both methyl groups $\mathrm{CH}_{3}-11$ at $\delta 0.84(\mathrm{~d}, 3.3 \mathrm{~Hz})$ and $\mathrm{CH}_{3}-12$ at $\delta 0.86(\mathrm{~d}, 3.3 \mathrm{~Hz})$ and $\mathrm{H}-10$ at $\delta 1.86(\mathrm{~m}) .{ }^{1} \mathrm{H}-{ }^{13} \mathrm{C}$ Long-range couplings were observed between H-8 and C-9 ( $\delta$ 37.7), C-10 ( $\delta$ 24.0), between both $\mathrm{H}-9 \mathrm{a}$ and $\mathrm{H}-9 \mathrm{~b}$ and $\mathrm{C}-8$, with the carbonyl group at $\delta 166.6$ (C-6 of 4-hydroxyproline, a ${ }^{4} J$ long-range correlation) and with $\mathrm{H}_{3} \mathrm{C}-12$, between $\mathrm{H}-10$ and $\mathrm{C}-8(\delta 52.5)$ and both methyl groups, as well as between the hydrogens of both methyl groups with C-10 and C-9. The LC-ESIMS of the mixture of $\mathbf{3}$ and $\mathbf{4}$ displayed a ion at $m / 2229$, sugesting the loss of $\mathrm{CH}_{4}$ from the leucyl-4-hydroxyproline molecular ion of small intensity at $m / z 245$. Negative-mode HRFABMS indicated a parent ion peak $\left[\mathrm{M}-\mathrm{H}^{+}\right]^{-}$at $\mathrm{m} / \mathrm{z}, 243.13476$ (calcd. 243.13448, $\Delta \mathrm{mu}+2.8$ ), confirming the molecular formula $\mathrm{C}_{11} \mathrm{H}_{20} \mathrm{~N}_{2} \mathrm{O}_{4}$ for 3 . Since we obtained only a tiny amount of this mixture, no attempt has been made in order to further purify the dipeptide leucyl-4-hydroxyproline (3), and the stereochemistry of the stereogenic centers were not determined. To the best of our knowledge, this is the first report on the identification of the linear dipeptide leucyl4-hydroxyproline (3). No chemical investigation of the $S$. acrimycini secondary metabolites has been previously reported, but only genetic and morphological descriptions. ${ }^{8-11}$

Although there is abundant literature data about dipeptides isolated from microbial sources, ${ }^{12,16}$ their true origin remains controversial. Some authors suggest that dipeptides are fermentation artifacts, generated by hydrolysis of proteins present in the growth media. ${ }^{16,17}$ However, several dipeptides isolated from microorganisms display relevant biological activities. ${ }^{14,15}$ Recently, it has been demonstrated that several dipeptides present an important role as chemical mediators of bacterial quorumsensing signalling systems. ${ }^{19}$ The isolation of unusual metabolites from the previously unstudied marine-derived S. acrimycini reinforce the importance of continuing studies on marine microbiology and on marine microorganisms secondary metabolism.

\section{Acknowledgments}

The authors thank to Dr. David E. Williams and Raymond J. Andersen (Departments of Chemistry and Earth and Ocean Sciences, University of British Columbia, Vancouver, Canada) as well as Dr. Brent Copp (Department of Chemistry, University of Auckland) for help in obtaining NMR and mass spectra, Fundação de Amparo à Pesquisa do Estado de São Paulo for a scholarship to ILCH and financial support, and to the technical staff of the Centro de Biologia Marinha of the Universidade de São Paulo for providing technical assistance during the sediments collection and logistic support.

\section{References}

1. Hyde, K. D.; Pointing, S. B.; Marine Mycology: A Practical Approach, $1^{\text {st }}$ ed., Fungal Diversity Research Series 1: Hong Kong, 2002.

2. Paul, J. H.; Marine Microbiology. Methods in Microbiology, Academic Press: New York, 2001, vol. 30.

3. Hernandez, I.L.C.; Godinho, M.J.L.; Magalhães, A.; Schefer, A.B.; Ferreira, A.G.; Berlinck, R.G.S.; J. Nat. Prod. 2000, 63 , 664.

4. Ishibashi, N.; Kouge, K.; Shinoda, I.; Kaneshisa, H.;Okai, H.; Agr. Biol. Chem. Tokyo 1988, 52, 819.

5. Martinez, J. S.; Zhang, G. P.; Holt, P. D.; Jung, H.-T.; Carrano, C. J.; Haygood, M. G.; Butler, A.; Science 2000, 287, 1245.

6. Xu, G. F.; Martinez, J. S.; Groves, J. T.;Butler, A.; J. Am. Chem. Soc. 2002, 124, 13408

7. Comin, V. J.; Keller-Schierlein, W.; Helv. Chim. Acta 1959, 42, 1730.

8. Asturias, J. A.; Martin, J. F.; Liras, P.; J. Ind. Microbiol. 1994, $13,183$.

9. Murray, I.A.; Gil, J. A.; Hopwood, D. A.; Shaw, W. V.; Gene 1989, 85, 283

10. Gil, J. A.; Kieser, H. M.; Hopwood, D. A.; Gene 1985, 38, 1.

11. Wright, H. M.; Hopwood, D. A.; J. Gen. Microbiol. 1977, 102, 417.

12. Kanzaki, H.; Yanagisawa, S.; Nitoda, T.; J. Antibiotics 2000 , 53,1257

13. Obata, Y.; Mizutani, J.; Bull. Agr. Soc. Japan 1958, 22, 14.

14. Yang, L.; Ren-xiang, T.; Wang, Q.; Huang, W.; Yin, Y.; Tetrahedron Lett. 2002, 43, 6545.

15. Otsuka, T.; Shibata, T.; Tsurumi, Y.; Takase, S.; Okuhara, M.; Terano, H.; Kohsaka, M.; Imanaka, H.; J. Antibiotics 1992 45,348

16. Prasad, C.; Peptides 1995, 16, 151.

17. Son, B. W.; Jensen, P. R.; Kauffman, C. A.; Fenical, W.; Nat. Prod. Lett. 1999, 13, 213.

18. Turner, W. B.; Aldridge, D. C.; Fungal Metabolites, $1^{\text {st }}$ ed., Academic Press: London, 1983

19. Holden, M.T.G.; Chabra, S.R.; de Nys, R.; Stead, P.; Bainton, N.J.; Hill, P.J.; Manefield, M.; Kumar, N.; Labatte, M.; England, D.; Rice, S.; Givskov, M.; Salmond, G.P.C.; Stewart, G.S.A.B.; Bycroft, B.W.; Kjelleberg, S.A.; Williams, P.; Mol. Microbiol. 1999, 33, 1254

Received: August 19, 2003 Published on the web: May 10, 2004

FAPESP helped in meeting the publication costs of this article. 